\title{
New significant advances of regional geological survey in the blank regions of Qinghai-Xizang Plateau
}

\author{
Zhai Gangyi \\ Bureau of China Geological Survey, Beijing, 100037, CHINA \\ For correspondence, E-mail: zgangyi@mail.cgs.gov.cn
}

Qinghai-Xizang Plateau provides an unparalleled opportunity to study the Tethyan evolution and the continental dynamics in which continents respond to subduction of slabs and collisional orogenesis. Many projects are mainly placed on this "key testing site" by geologists from all over the world. The main parts of Qinghai-Xizang Plateau are always the blank regions in the geological maps of large to intermediate scales of the mainland of China. Since 1999, approximately 1000 geologists from 32 geological survey institutes and scientific research academies are called for by the Bureau of China Geological Survey to conduct geological mapping in the blank regions of Qinghai-Xizang Plateau in an unparalleled fashion.

The blank regions not covered by geological survey in Qinghai-Xizang Plateau are up to $1.45 \times 10^{6} \mathrm{~km}^{2}$, which account for $60 \%$ of the total area of Qinghai-Xizang Plateau. They have been subdivided into 110 maps of regional geological survey at a scale of $1: 250,000$. Mapping of more than two third of the blank regions was completed by the end of last year. Significant progress has been made as evidenced from a large volume of new and important data obtained from the regional geological survey (Bureau of China Geological Survey, 2004a, 2004b, 2004c). These data are extensive and effective for interpretation and reevaluation of the geological problems that are related to the formation and evolution of Qinghai-Xizang Plateau.

Discoveries and identifications of a series of ophiolitic mélange zones, main faults and important regional discontinuities offer new, important information to reconstruct the tectonic framework and evolutional history in Qinghai-Xizang Plateau. The significant findings in Yarlung Zangbo ophiolitic mélange zone are $\mathrm{T}_{2-3}, \mathrm{~T}_{3}-\mathrm{J}_{1}$ radiolarian assemblages from argillaceous-siliceous rock in Tangga, Pomulong, and $\mathrm{T}_{2-3}$ radiolarian assemblages from siliceous rock in Zedang. An ophiolitic mélange zone called Shiquanhe-Namu Co-Jiali was identified in Gangdise. Identification of Hongliugou-Lapeiquan ophiolitic zone, Apa-Mangya ophiolitic zone (CambrianOrdovician) in A'erjin region and Qimayute-Qimantage ophiolitic zone (Cambrian-Ordovician), Yanbishan-Xiangyangshan ophiolitic zone (Ordovician-Carboniferous), Subashi-Muzitage ophiolitic zone (Carboniferous-Permian) in Kunlun mountain region enables reconstruction a clear evolutional history for the northern Qinghai-Xizang Plateau. Furthermore, Recognition of significant regional angular unconformities in Himalayas (Ordovician / metamorphic basement), Gangdise $\left(\mathrm{P}_{3} / \mathrm{P}_{2}\right.$, and $\mathrm{T}_{3} / \mathrm{P}_{3}, \mathrm{~J}_{1-2} / \mathrm{P}_{3}$ etc. $)$ and Qiangtang $\left(\mathrm{T}_{3} / \mathrm{J}_{2}\right)$ clearly show the evidences of orogenesis in different regions of Qinghai-Xizang Plateau (Wang et al. 2004).

The findings of a great deal of fossils provide the most important constraints for the stratigraphic framework, tectonic paleogeography and evolutionary history of Qinghai-Xizang Plateau. These kinds of data contain relatively continuous marine sedimentary records in the Himalayas and Gangdise, the mixed biota of the cool water biota with warmer water biota in the Upper Permian stratum of Gangdise, the Ordovician hornstones in
Qiangtang basin, the cool water biota with single channels in Jinyuhu area of northern Qinghai-Xizang Plateau, the Early Triassic conodonts, the Late Permian and Late Triassic pollens and spores in Bayankala Group etc.

A series of significant volcanic interlayers, abundant highquality isotopic ages of high-pressure metamorphic rocks, and magmatic rocks provide reliable chronological constraints in assessing the tectonic evolutional history of Tethys. Eleven volcanic interlayers that are mainly characterized by intermediate-basic from Permian to Cretaceous in Tethyan Himalayas (Zhu et al. 2004) and the Late Paleozoic volcanic interlayers are mainly composed of basalt, andesite, dacite, and rhyodacite in Gangdise (Wang et al. 2004) provide possibilities to study the continental breakup of northern margin of Gondwana and the tectonic evolution of Gangdise in the Late Paleozoic. The findings of basic granulites in Yadong, central segment of Higher Himalayas (zircon SHRIMP ages distributed at $1.99 \mathrm{Ga} \pm 0.03 \mathrm{Ga}, 29.5 \mathrm{Ma} \pm 0.4 \mathrm{Ma}, 17.6 \mathrm{Ma} \pm 0.3 \mathrm{Ma}$ ), the 525 $\mathrm{Ma} \sim 553 \mathrm{Ma}$ crystalline ages of granite from rock suite of Namche Barwa, and the granodiorite with huge phenocrysts (concordant age of zircon is $217.1 \pm 3.4 \mathrm{Ma}$ ) from Gangdise, together with the leucitic phonolites, high-K lithophysa rhyolites (48 Ma) from Yangbajing, hornblende aegirite augitic syenite (15.8 Ma) from the western Gangdise, as well as the granulite, eclogite, and the granitic gneiss (zircon SHRIMP age is $856 \mathrm{Ma} \pm 12 \mathrm{Ma}$ ) from the complex of A'erjinshan, are very much important for understanding the tectonic evolution of the Tethys zone and Qinghai-Xizang Plateau.

The abundant and useful information on new findings of numbers of mineral resources are valuable for the regional economic development. More than 500 deposits and mineralized spots have been found in the process of regional geological survey. A significant number of these newly found mineralizations serve as potential large-scale and super large-scale deposits. In addition, 9 major mineralization belts of polymetals including $\mathrm{Cu}, \mathrm{Fe}, \mathrm{Pb}, \mathrm{Zn}$, and $\mathrm{Ag}$ also have been recognized.

A large dataset obtained newly on Cenozoic tectonics and Quaternary sedimentary records of terrestrial and lacustrine facies is valuable to study the collisional behavior, the process of uplift and the environmental evolution for the Qinghai-Xizang Plateau. The angular unconformities between Dazhuka and Lamayejia Formations in southern margin of Gangdise, the Zu'erkenwulashan (Ez) and Tuotuohe (Et) Formation in northern Qinghai-Xizang Plateau yield information that is useful for evaluation of collisional behavior of the continent-continent type. Thirty eight levels of lacustrine terraces from the northern bank of Peiku Co and $153.95 \mathrm{~m}$ thick sedimentary record of glacial lacustrine facies from Paixiang-Yusong in eastern Tibet show characteristics of Barrier Lakes. While the sedimentary records such as 119 m higher than the lake level from Zabuyechaka-Taruo Co-Xueli Co-Kongqie Co, as well as the 130-140 m higher than the lake level from peri-Namu Co indicate that there was a huge paleo-lake (the area exceeded $10 \times 10^{4} \mathrm{~km}^{2}$ ) in the late Pleistocene 
in the northern Tibetan Plateau. The five terraces of continental river from Nuomuhong in the northern Qinghai-Xizang Plateau provide significant information in order to understand the climate change and the uplift of Plateau.

A lot of cultural relics provide important opportunities to study the culture of paleo-humanity in Qinghai-Xizang Plateau. Five activity relics of paleo-humanity (including 390 stone implements and also pottery fragments) from Zadong, Qiongguo, Saga, Dajia Co in Himalayas, and 3 stone implements, 1 tooth of large animal from Kumu'ewulazi in eastern Kunlunshan have been found. These data show the history of paleo-humanity activity at about 7 4 KaB.P. and 10 KaB.P. in Qinghai-Xizang Plateau.

Under the deployment of Bureau of China Geological Survey, the new version of geological map of Qinghai-Xizang Plateau and its adjacent regions $\left(25^{\circ}\right.$ to $40^{\circ} \mathrm{N}$ latitudes, $72^{\circ}$ to $106^{\circ}$ E longitudes) at 1:1,500,000 scale was completed. This was accomplished through the use of the knowledge and experience of mapping of Chinese as well as foreign geologists on geological phenomena in Qinghai-Xizang Plateau gathered during the last two decades. Of special importance were the new data gathered during the geological surveying at 1:250, 000 scale in the blank regions of Qinghai-Xizang Plateau. This new version geological map is essential graphic guide for the researchers from all over the world for carrying out research on geology and other related scientific fields on Qinghai-Xizang Plateau.

\section{References}

Bureau of China Geological Survey. 2004a. The results and advances of regional geological survey in Himalayas. In: Special issue on the first group of results in 1:250 000 geological mapping in the Qinghai-Tibet Plateau, Geological Bulletin of China 23(1): 27-39 (in Chinese)

Bureau of China Geological Survey. 2004b. The results and advances of regional geological survey in Gangdise. In: Special issue on the first group of results in 1:250 000 geological mapping in the Qinghai-Tibet Plateau, Geological Bulletin of China 23(1), 45-60 (in Chinese)

Bureau of China Geological Survey. 2004c. The results and advances of regional geological survey in A'erjin-Kunlun mountain. In: Special issue on the first group of results in 1:250 000 geological mapping in the Qinghai-Tibet Plateau, Geological Bulletin of China 23(1): 68-96 (in Chinese)

Wang L, D Zhu and G Pan. 2004. Primary Results and Progress of Regional Geological Survey (1:250, 000): the South of Qinghai-Tibet Plateau. Geological Bulletin of China 23(6), in press (in Chinese with English abstract).

Zhu D, G Pan, X Mo X and others. 2004. The volcanic activities in the central segment of Tethyan Himalayas from Permian to Cretaceous (I): Distributions and Significances. Geological Bulletin of China 23(5), in press (in Chinese with English abstract) 